\title{
Impact of Municipal Waste Water on Growth and Nutrition of Afforested Pinus eldarica Stands
}

\author{
Masoud Tabari, Azadeh Salehi and Jhangard Mohammadi \\ Tarbiat Modares University \\ Iran
}

\section{Introduction}

As a whole, water is a most important source for plantations particularly in the dry regions (Mosadegh, 1999). In other hand, wastewater can be used to cover the needs of urban and rural areas and parks as well as industrial complexes to develop green space and to reduce air pollution (Al-Jamal et al., 2000; Singh and Bhati, 2005; Sharma, et al., 2007). In reality, wastewater except the water resource for irrigating the plantations is an enormous nutrient source, too (Meli et al., 2002; Rattan et al., 2005). Of course, establishment of trees plantation for waste water irrigation has been a common practice for many years. The practice not only defers ecological degradation by the pollutants in the soil, because trees are long-living organisms which can take up trace elements from the soil, water or air and retain them for a long time (Madejo'n et al., 2006). But it also creates opportunities for commercial biomass production and sequestration of excess minerals in the plant system (Sharma and Ashwath, 2006). Therefore, the use of waste water in growing woodlots is a viable option for the economic disposal of waste water (Neilson et al., 1989). Moreover, waste water from municipal origin is rich in organic matter and also contains appreciable amounts of macro and micro-nutrients (Gupta et al., 1998). Accordingly nutrients levels of soil are expected to improve considerably using continuous irrigation with municipal waste water (RamirezFuentes et al., 2002; Rattan, et al., 2005). Apart from this, in the case of the utilization of wastewater mixed with harmful heavy metals lead to decrease the toxicity, through a developed rooting system in plantations (Karpiscak et al., 1996) and as such, play the important and fundamental role for the environmental protection (Cromer et al., 1987; Stewart et al., 1990). However, this can not be ignored that the use of wastewater for irrigation purposes might damage the ecosystem because the high toxic concentration and heavy metals (Gupta et al., 1998; Brar et al., 2000; Yadav et al., 2002). The accumulation of heavy metals in soil is related to $\mathrm{pH}$, texture and cation exchange capacity of soil (Datta et al., 2000). Therefore, decision about the application of wastewater should be made based on the views of specialties of water, soil, plant and environment of every location (Nagshinepour, 1998).

Iran is a part of arid regions in the world being encountered acute crises owing to the increased population and need of water resources (Tabatabaei, 1998). It is noteworthy saying that thousands liters of domestic, industrial and hospital effluents are daily flowing from Tehran metropolitan area and influence the underground water resources. In the same way, 80 percent of the useful water of the citizens in Tehran is also transformed as 
municipal effluent (Tajrishi, 1998). On the other side, unplanned expansion and air pollution of Tehran make it unavoidable to increase the green space. In reality, urban green space and green belt around the city can play an effective role in air purification and climate health. Since the lack of water is a limiting factor for development of green space, therefore municipal effluent may be suitable (Torabian and Hashemi, 1999).

Till now inside the country several researches have been conducted about effect of municipal effluent on soil and agricultural crops, but not on softwoods. The objective of this study was to investigate the effects of the 15 years municipal waste water application on the growth of Pinus eldarica Medw. trees and the minerals accumulation in the trees needles.

\section{Materials and methods}

The study site is an abandoned agriculture site located in Shahr-e Rey, $5 \mathrm{Km}$ south of Tehran-Iran (Latitude $35^{\circ} 37^{\prime} \mathrm{N}$, Longitude $51^{\circ} 23^{\prime} \mathrm{E}, 1005 \mathrm{~m}$ above sea level). The climate of the site is semi-arid with mild-cold winters and 7 months (Mid April-Mid November) dry season (Fig. 1). Average annual rainfall and average annual temperature are $232 \mathrm{~mm}$ and $13.3^{\circ} \mathrm{C}$, respectively. The highest rainfall appears in March and the lowest in August. The warmest month occurs in August and the coldest in January. Experiment was conducted at two 4 hectare even-aged (15 years) artificial stand of Pinus eldarica Medw. The first stand was irrigated with municipal waste water and the second with well water since plantation. The irrigation was applied daily based on tree water-use and the potential evapotranspiration, which varied seasonally in response to the climate. The soils of both fields were clay-loam with $32.5 \%$ clay, $34.12 \%$ silt and $33.38 \%$ sand in the field irrigated with municipal waste water and $28.52 \%$ clay, $36 \%$ silt and $35.48 \%$ sand in the field irrigated with well water

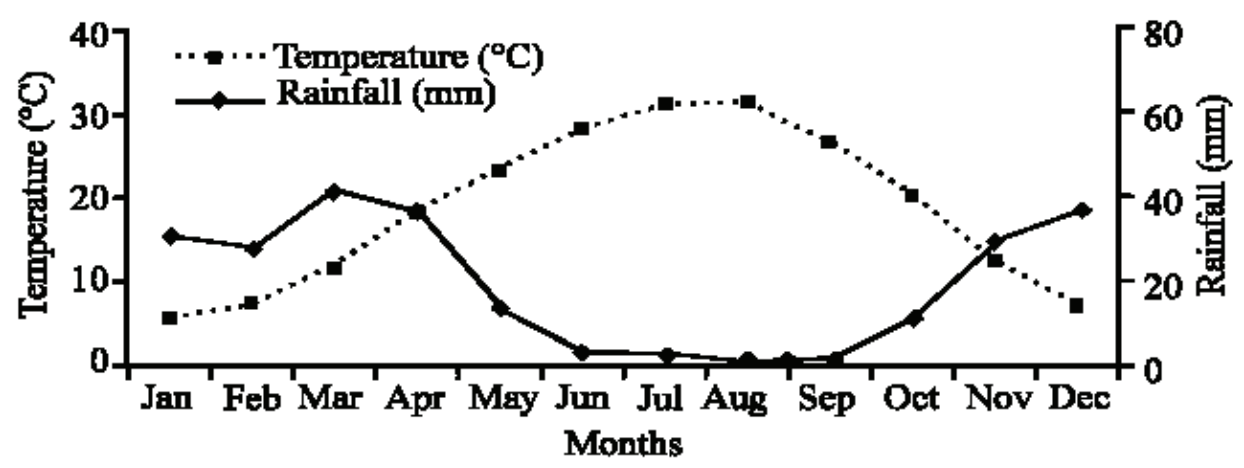

Fig. 1. Embrothermic curve of the study site

The study was established in October 2006. Data was collected using technique of systematic random sampling (Jayaraman, 2000) with 4 replications in either of both fields. Therefore, four plots were identified in each field of irrigated with municipal waste water and well water. Plots were $30 \mathrm{~m} \times 30 \mathrm{~m}$, with tree spacing of $3 \mathrm{~m} \times 4 \mathrm{~m}(833 / \mathrm{ha})$. In each plot, diameter at breast height (d.b.h.), total height, crown length and crown diameter of total trees were measured and basal area computed. Standing volume of each tree was determined by using form factor $(\sim 0.5)$ and formula $\mathrm{V}=0.4 \times \mathrm{D}^{2} \times \mathrm{H}$, made by Zobeyri 
(1994). Where, $\mathrm{D}$ is diameter at breast height (d.b.h.), $\mathrm{H}$ is total height and $\mathrm{V}$ is standing volume.

In each plot, four trees were selected and at the end of growing season needle samples of $P$. eldarica trees taken from the top of crown and the part affected by sunlight (Letacon, 1969; Habibi Kaseb, 1992). This collection provided 16 needle samples in each treatment. At the end of the sampling, one representative needle sample from each plot (by mixing of four samples of each plot) was taken (due to decreasing of samples quantity for chemical analysis). Municipal waste water and well water were sampled daily (3 days in each month) from early June to late November, at three times per day (morning, noon and evening) to make a composite sample of each day.

Water samples were brought to the laboratory in resistant plastic bottles to avoid adherence to the container wall. They were filtered through $42 \mathrm{~mm}$ filter paper and stored at $4{ }^{\circ} \mathrm{C}$ to minimize microbial decomposition of solids (Yadav et al., 2002; Bhati and Singh, 2003). Several parameters were measured separately, $\mathrm{pH}$ and $\mathrm{EC}$ by the procedure described using OMA (1990), $\mathrm{NH}_{4}-\mathrm{N}, \mathrm{NO}_{3}-\mathrm{N}, \mathrm{PO}_{4}-\mathrm{P}, \mathrm{K}, \mathrm{Ca}, \mathrm{Mg}$ and $\mathrm{Na}$ as per the method given by APHA (1992) and Yadav et al. (2002).

Fresh weight of some needles from each treatment was recorded immediately after harvest. Dry weight was recorded after oven drying of needles for $72 \mathrm{~h}$ at $80{ }^{\circ} \mathrm{C}$ (Bhati and Singh, 2003). Samples of needle were washed using tap water, rinsed with distilled water, oven dried at $80^{\circ} \mathrm{C}$ for $24 \mathrm{~h}$ (Singh and Bhati, 2005), ground in a stainless steel mill and retained for mineral analysis. For determination of macro and micro-nutrients exception $\mathrm{P}$ and $\mathrm{N}$, the needle samples were wet digested as per Jackson (1973) and estimated using an Atomic Absorption Spectrophotometer (AAS). Measurement of P content was performed after a wet digestion using UV-VIS spectrophotometer at $450 \mathrm{~nm}$ (Singh and Bhati, 2005). The N content of needle samples digested in concentrate sulfuric acid was determined by the Kjeldahl method (Bhati and Singh, 2003; Bozkurt and Yarilga, 2003).

Average growth parameters and needle nutrients of two irrigation treatments $\left(\mathrm{T}_{1}\right.$ : irrigation by municipal waste water; $\mathrm{T}_{2}$ : irrigation by well water) were compared using independentsamples t-test. The variations in characteristics of municipal waste water and well water were firstly tested for normality using Shapiro-Wilk's test and then by independent-samples t-test. All the data were analyzed using the SPSS statistical package.

\section{Results and discussion}

\subsection{Waste water and well water}

Results indicated that the waters were alkaline in reaction (Table 1). The $\mathrm{pH}$ of the municipal waste water in various months ranged from 7.51 to 7.75 and for well water 6.69 to 7.62. Based on results of Patel et al. (2004), in our examination the tolerance limit of $\mathrm{pH}$ for irrigation ranged from 6.0 to 9.0. The electrical conductivity (EC) of municipal waste water ranged from 1.78 to $2.12 \mathrm{dS} \mathrm{m}^{-1}$ with the greatest value detected in August. Average EC of municipal waste water (mean of 18 samples) exceeded $1 \mathrm{dS} \mathrm{m}^{-1}\left(1.91 \mathrm{dS} \mathrm{m}^{-1}\right)$ indicating the waste water was saline in nature (Rattan et al., 2005). The $\mathrm{pH}$ and EC of the municipal waste water were greater than those of the well water. The concentration of all the nutrient elements was higher in municipal waste water, with $\mathrm{NO}_{3}-\mathrm{N}$ content $\left(1.63 \mathrm{mg} \mathrm{l}^{-1}\right)$ being 6.8 times the content in well water $\left(0.24 \mathrm{mg} \mathrm{l}^{-1}\right)$. The content of $\mathrm{NH}_{4}-\mathrm{N}$ in municipal waste water $\left(9.05 \mathrm{mg} \mathrm{l}^{-1}\right)$ was also 4.2 times the content in well water $\left(2.15 \mathrm{mg} \mathrm{l}^{-1}\right)$. On average, available content of $\mathrm{PO}_{4}-\mathrm{P}, \mathrm{K}^{+}, \mathrm{Ca}^{2+}, \mathrm{Mg}^{2+}, \mathrm{Na}^{+}$in municipal waste water were greater compared to 
those in the well water. The most nutrients concentration of municipal waste water were reduced in autumn and increased in summer because of high temperature and evaporation losses of water (Singh and Bhati, 2005).

Although municipal waste water elevated significantly $(P<0.01)$ in all values compared to well water, but the analysis showed that $\mathrm{pH}, \mathrm{EC}, \mathrm{NO}_{3}-\mathrm{N}, \mathrm{PO}_{4}-\mathrm{P}, \mathrm{K}^{+}, \mathrm{Na}^{+}$of well water samples were within the limits as per the standard prescribed for land disposal and should not pose any serious hazard according to threshold values of WHO (Hach, 2002). However, the contents of $\mathrm{NH}_{4}-\mathrm{N}$ and $\mathrm{Ca}^{2+}$ of municipal waste water and well water and $\mathrm{Mg}^{2+}$ of municipal waste water were on the higher side (Table 1).

\begin{tabular}{|c|c|c|c|c|c|}
\hline \multirow{2}{*}{ Parameters } & \multicolumn{2}{|c|}{ Municipal waste water } & \multicolumn{2}{|c|}{ Well water } & \multirow{2}{*}{$\mathrm{WHO}^{*}$} \\
\hline & $\begin{array}{c}\text { Range } \\
\text { (Min.-Max.) }\end{array}$ & Mean \pm SE & $\begin{array}{c}\text { Range } \\
\text { (Min.-Max.) }\end{array}$ & Mean \pm SE & \\
\hline $\mathrm{pH}$ & $7.51-7.75$ & $7.63 \pm 0.01 \mathrm{a}$ & $6.69-7.62$ & $7.32 \pm 0.05^{b}$ & $\begin{array}{l}6.5- \\
8.5\end{array}$ \\
\hline $\mathrm{EC}\left(\mathrm{dS} \mathrm{m}^{-1}\right)$ & $1.78-2.12$ & $1.91 \pm 0.02 \mathrm{a}$ & $0.54-0.67$ & $\begin{array}{c}0.590 \pm 0.008 \\
\mathrm{~b}\end{array}$ & 3 \\
\hline $\mathrm{NH}_{4}-\mathrm{N}\left(\mathrm{mg} \mathrm{l}^{-1}\right)$ & $8.1-10.24$ & $9.05 \pm 0.11 \mathrm{a}$ & $1.83-2.49$ & $2.15 \pm 0.19 b$ & 1.5 \\
\hline $\mathrm{NO}_{3}-\mathrm{N}\left(\mathrm{mg} \mathrm{l}^{-1}\right)$ & $1.58-1.89$ & $1.63 \pm 0.09 \mathrm{a}$ & $0.19-0.33$ & $0.24 \pm 0.08^{b}$ & 3 \\
\hline $\mathrm{PO}_{4}-\mathrm{P}\left(\mathrm{mg} \mathrm{l}^{-1}\right)$ & $11.45-14.13$ & $12.69 \pm 0.16^{a}$ & $4.62-5.64$ & $5.03 \pm 0.01 \mathrm{~b}$ & --- \\
\hline $\mathrm{K}\left(\mathrm{mg} \mathrm{l}^{-1}\right)$ & $33.06-46.31$ & $39.93 \pm 0.83 \mathrm{a}$ & $17.48-22.75$ & $19.72 \pm 0.36^{b}$ & - \\
\hline $\mathrm{Ca}\left(\mathrm{mg} \mathrm{l}^{-1}\right)$ & $\begin{array}{c}235.54- \\
296.20\end{array}$ & $\begin{array}{c}255.22 \pm 4.57 \\
\text { a }\end{array}$ & $66.70-101.57$ & $96.77 \pm 1.26^{b}$ & 75 \\
\hline $\operatorname{Mg}\left(\mathrm{mg} \mathrm{l}^{-1}\right)$ & $100.9-124$ & $\begin{array}{c}109.85 \pm 1.83 \\
a\end{array}$ & $28.9-42$ & $35.22 \pm 0.79 b$ & 50 \\
\hline $\mathrm{Na}\left(\mathrm{mg} \mathrm{l}^{-1}\right)$ & $\begin{array}{c}135.90- \\
150.22\end{array}$ & $\begin{array}{c}140.45 \pm 0.20 \\
\text { a }\end{array}$ & $30.18-41.03$ & $35.18 \pm 0.13 b$ & 200 \\
\hline
\end{tabular}

Different superscripts in row indicate significant $(P<0.01)$ difference. Values are mean of eighteen replications ( 3 days $\times 6$ months) with \pm SE; ${ }^{*}$ World Health Organization $(W H O)$ : Hach, 2002

Table 1. Characteristics of municipal waste water and well water

\subsection{Tree growth}

Irrigation with municipal waste water for 15 years produced the largest trees in this treatment. The most frequent trees were found at diameter class of $20 \mathrm{~cm}$ and $14 \mathrm{~cm}$, respectively grown on field irrigated with municipal waste water and well water (Fig. 2). In fact, tree growth was greater $(P<0.01)$ in the field irrigated using municipal waste water than in plots irrigated with well water, as indicated by the $17.95 \pm 1.33 \mathrm{~cm}$ diameter at breast height, $10.04 \pm 0.15 \mathrm{~m}$ height, $8 \pm 0.27 \mathrm{~m}$ crown length, $2.53 \pm 0.17 \mathrm{~m}$ crown average 
diameter, $264.20 \pm 30.02 \mathrm{~cm}^{2}$ basal area and $0.139 \pm 0.013 \mathrm{~m}^{3}$ standing volume of the trees in waste water irrigated field (Table 2). Similarly, an increase in the growth of olive (Olea europaea) trees due to irrigation with municipal waste water has been reported by Aghabarati et al. (2008). The study of Stewart et al. (1990) also suggested that the addition of municipal waste water on Eucalyptus grandis has been resulted in a doubling of growth rate when compared to $E$. grandis grown in a rain fed site in four years.

The increased growth may be linked to sufficient availability of water and better status of nutrients in soil (Larchevêque et al., 2006). Since municipal waste water contains plant nutrients and organic matter, it may improve the properties of soil for increase in growth and biomass production (Guo et al., 2002; Egiarte et al., 2005; Lopez et al., 2006). The increase in growth indicates that waste water application influenced the physiological processes, facilitated early needle initiation and resulted in a net increase in the number of needles. An increase in needles could have captured more solar energy for metabolic use, fixed more $\mathrm{CO}_{2}$, and produced greater photosynthesis, and growth. This hypothesis is supported by Ceulemans et al. (1993) and Myers et al. (1996).

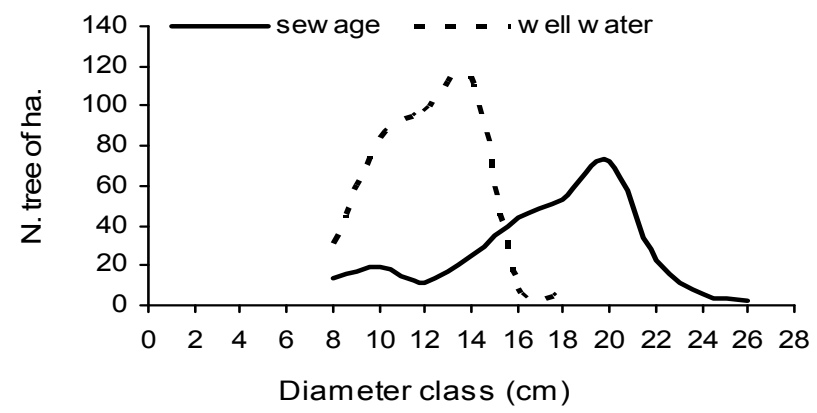

Fig. 2. Distribution of diameter classes for P. eldarica trees in two irrigation types

\begin{tabular}{|c|c|c|c|c|c|c|}
\hline Irrigation type & $\begin{array}{c}\text { Diameter at } \\
\text { breast } \\
\text { height }(\mathrm{cm})\end{array}$ & $\begin{array}{c}\text { Height } \\
(\mathrm{m})\end{array}$ & $\begin{array}{c}\text { Crown } \\
\text { length } \\
(\mathrm{m})\end{array}$ & $\begin{array}{c}\text { Crown } \\
\text { diameter } \\
(\mathrm{m})\end{array}$ & $\begin{array}{c}\text { Basal } \\
\text { area } \\
\left(\mathrm{cm}^{2}\right)\end{array}$ & $\begin{array}{c}\text { Standing } \\
\text { volume } \\
\left(\mathrm{m}^{3}\right)\end{array}$ \\
\hline $\begin{array}{c}\text { Trees irrigated } \\
\text { with waste water }\end{array}$ & $\begin{array}{c}17.95 \mathrm{a} \\
(1.33)\end{array}$ & $\begin{array}{c}10.04 \mathrm{a} \\
(0.15)\end{array}$ & $\begin{array}{c}8.0 \mathrm{a} \\
(0.27)\end{array}$ & $\begin{array}{c}2.53 \mathrm{a} \\
(0.17)\end{array}$ & $\begin{array}{c}264.20 \mathrm{a} \\
(30.02)\end{array}$ & $\begin{array}{c}0.139 \mathrm{a} \\
(0.013)\end{array}$ \\
\hline $\begin{array}{c}\text { Trees irrigated } \\
\text { with well water }\end{array}$ & $\begin{array}{c}13.50 \mathrm{~b} \\
(0.5)\end{array}$ & $\begin{array}{c}9.02 \mathrm{~b} \\
(0.10)\end{array}$ & $\begin{array}{c}7.3 \mathrm{~b} \\
(0.12)\end{array}$ & $\begin{array}{c}1.90 \mathrm{~b} \\
(0.20)\end{array}$ & $\begin{array}{c}135.0 \mathrm{~b} \\
(20.5)\end{array}$ & $\begin{array}{c}0.65 \mathrm{~b} \\
(0.09)\end{array}$ \\
\hline
\end{tabular}

-Different superscripts in column indicate significant difference of each tree attribute between two irrigation types.

-Values in parenthesis are $\pm \mathrm{SE}$.

Table 2. Effect of municipal waste water and well water on growth of $P$. eldarica trees

\subsection{Mineral composition of needles}

The application of municipal waste water significantly increased the macro-elements $(\mathrm{N}, \mathrm{P}$, $\mathrm{K}, \mathrm{Ca}, \mathrm{Mg}$, Na concentration of $P$. eldarica trees needle as compared with well water (Table 
3). Increases in minerals concentration may have been due to the effect of nutrients addition through municipal waste water (Meli et al., 2002). This result is in agreement with Singh and Bhati (2005) and Aghabarati et al. (2008), whereas a substantially greater above-mentioned minerals concentration were observed in leaf of Dalbergia sissoo seedlings and Olea europaea trees irrigated with municipal waste water compared to control. However, Guo et al. (2002) and Aghabarati et al. (2008) had also suggested that a decrease of $\mathrm{Mg}$ and $\mathrm{Ca}$, and no difference of $\mathrm{Na}$ concentration in leaf of eucalypt and olive tree were treated by municipal waste water. In fact, quantity of nutrients absorption using plant depends upon the total quantity of the nutrients applied through waste water application, soil properties and type of plant (Bozkurt and Yarilga, 2003). The minerals concentration of needle may be ranked from greatest to least as $\mathrm{N}>\mathrm{Ca}>\mathrm{K}>\mathrm{Mg}>\mathrm{P}>\mathrm{Na}$.

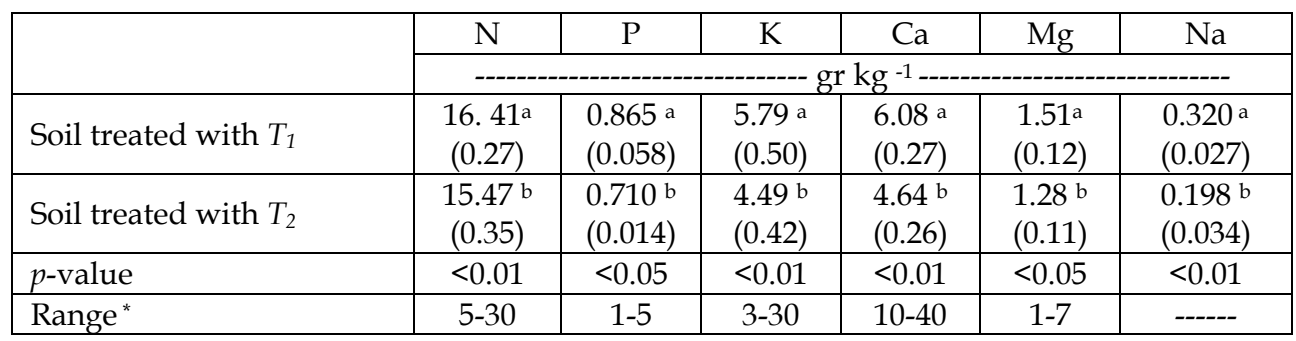

Abbreviations: $T_{1}$ : municipal waste water; $T_{2}$ : well water; values are mean of four replications with $\pm \mathrm{SD}$ in parentheses; different superscripts in column indicates significant difference between $T_{1}$ and $T_{2}$; * Salardini (1992)

Table 3. Mineral composition of $P$. eldarica trees needle by affected by municipal waste water and well water

\section{Conclusion}

Our study displayed that all growth parameters measured in P. eldarica trees were statistically greater in effluent-irrigated area than in well-watered area. As a whole, the use of municipal effluent in irrigations can be an overflowing resource from the nutrient elements required for plants (Yadav et al., 2002; Mapanda et al., 2005; Toze, 2006). As a matter of fact, high nutrient concentrations in effluent, compared to those in well water, cause the nutrient accumulation in the soil (Stewart and Flinn, 1984; Phillips et al., 1986; Stewart et al., 1990; Keller et al., 2002; Selivanovskaya et al., 2002; Emongor and Ramolemana, 2004) and makes easy the access of plants to the high nutrient concentration (macro and micro elements) and increases their growth. Accordingly, in agreement with our findings the results of Stewart and Flinn (1984, on Pinus eldarica), Phillips et al. (1986, Pinus eldarica), Ostos et al. (2007, on Pistacia lentiscus) show that faster growth of tree occurs in the effluent-irrigated areas. This is mostly due to high nutrient concentration in effluent. It may be also noted that the nutrient contents in the municipal effluent is more than needed by plants whereas in the such conditions trees can produce greater biomass (Fitzpatrick et al., 1986; Martinez et al., 2003; Sing and Bhati, 2005; Guo et al., 2006). Regarding the differences indicated above and positive effects of effluent on the growth of $P$. eldarica, it can be recommended that the produced huge municipal effluent in south of Tehran can be used for accomplishment of plantation projects and for development of rural and urban green spaces and green belts around the city and for reduction of air pollution, too. It is necessary to 
clarify that the decision for each location should be made based on accurate management, chemical, physical and microbial characteristics of water, soil and plant, according to international standards.

\section{Acknowledgement}

Authors are thankful to Natural Resources Faculty of Tarbiat Modares University for providing research facilities and funding of this research and to Department of Forestry for technical and scientific assistance. We gratefully acknowledge Shahr-e-Ray Municipality for their support on field assistance of this research.

\section{References}

Aghabarati, A.; Hosseni, S.M, Esmaeili, A. \& Maralian, H. (2008). Growth and mineral accumulation in Olea europaea L. trees irrigated with municipal effluent. Res. J. Environ. Sci., 2 (4): 281-290.

Al-Jamal, A.M.S.; Sammis, T.W.; Mexal, J.G.; Picchioni G.A. \& Zachritz, W.H. (2000). A growth irrigation scheduling model for wastewater use in forest production. Agricultural Water Management, 56: 57-79.

APHA. (1992). Standard Methods For The Examination OF Water And Wastewater. APHA, AWWA and WPCF. 16th ed.

Bhati, M. \& Singh, G. (2003). Growth and mineral accumulation in Eucalyptus camaldulensis seedlings irrigated with mixed industrial effluents. Bioresource Technol., 88: 221-228.

Bozkurt, M.A. \& Yarilga, T. (2003). The effects of waste water sludge applications on the yield, growth, nutrition and heavy metal accumulation in apple trees growing in dry conditions. Turk. J. Agric. For, 27: 285-292.

Brar, M.S., S.S. Mahli, A.P. Singh, C.L. Arora and K.S. Gill, 2000. Sewer water irrigation effects on some potentially toxic trace elements in soil and potato plants in northwestern India. Can. J. Soil Sci., 80: 465-471.

Ceulemans, R.J.; Pontailler, F.M. \& Guittet, J. (1993). Leaf allometry in young poplar stands: reliability of leaf area index estimation, site and clone effects. Biomass Bioenerg., 4: 769-776.

Cromer, R.N., P. Tompkins and N.J. Barr, 1987. Irrigation of Pinus radiata with waste water: tree growth in response to treatment. Aus. Forest Res., 13: 57-65.

Datta, S.P.; Biswas, D.R.; Saharan, N.; Ghosh, S.K. \& Rattan, R.K. (2000). Effect of long-term application of sewage effluents on organic carbon, bioavailable phosphorus, potassium and heavy metals status of soils and uptake of heavy metals by crops. $J$. Indian Soc. Soil Sci., 48: 836-839.

Egiarte, G.; Arbestian, C.M.; M., Alonso, A.; Rui'Z-Romera E. \& Pinto, M. (2005). Effect of repeated applications of waste water sludge on the fate of $\mathrm{N}$ in soils under Monterey pine stands. For. Ecol. Manage. 216: 257-269.

Emongor, V.E. \& Ramolemana, G.M. (2004). Treated sewage effluent (water) potential to be used for horticultural production in Botswana. Physics and Chemistry of the Earth, 29: 1101-1108. 
Fitzpatrick, G.E., Donselman H. \& Carter, N.S. (1986). Interactive effects of sewage effluent irrigation and supplemental fertilization on container - grown trees. Hort. Science, 21(1): 92-93.

Guo, L.B.; Sims, R.E.H.; Horne, D.J. (2002). Biomass production and nutrient cycling in Eucalyptus short rotation energy forests in New Zealand. I: biomass and nutrient accumulation. Bioresource Technol., 85: 273-283.

Guo, L.B.; Sims, R.E.H. and Horne, D.J. (2006). Biomass production and nutrient cycling in Eucalyptus short rotation energy forests in New Zealand: II. Litter fall and nutrient return. Biomass and Bioenergy, 30: 393-404.

Gupta, A.P.; Narwal, R.P.; Amtil, R.S. (1998). Sewer water composition and its effect on soil properties. Bioresource Technol., 65: 171-173.

Habibi Kaseb, H. (1992). Forest Pedology. Tehran University Press, 424 pp.

Hach, C. (2002). Water Analysis Handbook, Loveland, Colorado, USA, p. 61-62.

Jackson, M.L. (1973). Soil Chemical Analysis. Prentice Hall of India Private Ltd., New Delhi.

Jayaraman, K. (2000). A Statistical Manual for Forestry Research. FORESPA Publication., 240 pp.

Karpiscak, M.M.; Gerba, C.P.; Watt, P.M.; Foster K.E. \& Falabi, J.A. (1996). Multi-species plant systems for wastewater quality improvement and habitat enhancement. International association on water quality. Water Sci. Technol., 33: 231-236.

Keller, C.; Grath, S.P.Mc. \& Dunham, S.J. (2002). Trace metal leaching through a soil grassland system after sewage sludge application. J. Environ. Qual., 31: 1550-1560.

Larchevarcheveque, M.; Ballini, C., Korboulewsky N. \& Montes, N. (2006). The use of compost in afforestation of Mediterranean areas: Effects on soil properties and young tree seedlings. Sci. Total Environ., 369: 220-230.

Letacon, F. (1969). Une methode originale de prelevemennts foliaires, R.F.F. 3: 196-197.

Lopez, A.; Pollice, A.; Lonigro, A.; Masi, S.; Palese, A.M.; Cirelli, G.L.; Toscano, A. \& Passino, R. (2006). Agricultural wastewater reuse in southern Italy. Desalination. 187: 323334.

Madejon, P.; Maranon, T. \& Murillo, J.M. (2006). Biomonitoring of trace elements in the leaves and fruits of wild olive and holm oak trees. Sci. Total Environ. 355: 187-203.

Martinez, F.; Cuevas, G.; Calvo R. \& Walter, I. (2003). Biowaste effects on soil and native plants in semiarid ecosystem. J. Environ. Qual., 32: 472-9.

Meli, S.; Porto, M.; Bellingo, A.; Bufo, S.A.; Mazzatura, A. \& Scopa, A. (2002). Influence of irrigation with lagooned urban wastewater on chemical and microbiological soil parameters in a citrus orchard under Mediterranean condition. Sci. Total Environ., 285: 69-77.

Mosadegh, A. (1999). Plantation and Forest Nurseries. University of Tehran Press. 516 pp.

Myers, B.J.; Theiveyanath, S.O.; Brian, N.O. \& Bond, W.J. (1996). Growth and water use of Eucalyptus grandis and Pinus radiata plantations irrigated with effluent. Tree Physiol., 16: 211-219.

Naghshinehpour, B. (1998). Application of effluent in agriculture productions and soil rehabilitation. First congress on the programming and policy in infrastructural matter (water and soil), Ministry of Agriculture. 
Neilson, G.H.; Stevenson, D.S.; Fitzpatrick, J.J. \& Brownlee, C.H. (1989). Nutrition and yield of young apple trees irrigated with municipal waster water. J. Am. Soc Hortic. Sci., 114: 377-383.

OMA, (1990). Official Methods of Analysis. 15th ed. Association of Official Analytical Chemists, Arlington, Virginia, USA.

Ostos, J.C.; Pez-Garrido, R.Lo.; Murillo, J.M. \& Lo'pez, R. (2007). Substitution of peat for municipal solid waste- and sewage sludge-based composts in nursery growing media: Effects on growth and nutrition of the native shrub Pistacia lentiscus L. Bioresource Technology.

Patel, K.P.; Pandaya, R.R.; Maliwal, G.L.; Patel, K.C.; Ramani, V.P. \& George, V. (2004). Heavy metal content of different effluents and their relative availability in soils irrigated with effluent waters around major industrial cities of Gujarat. J. Ind. Soc. Soil Sci., 52: 89-94.

Phillips, R.; Fisher J.T. \& Mexal, J.G. (1986). Fuelwood production utilizing Pinus eldarica and sewage sludge fertilizer. Forest Ecology and Management, 16: 95-102.

Ramirez-Fuentese, Lucho-Constsntino, C.; Escamilla-Silva, E. \& Dendooven, L. (2002). Characteristics and carbon and nitrogen dynamics in soil irrigated with waste water for different lengths of time. Bioresource Technol., 85: 179-187, 2002.

Rattan, R.K.; Datta, S.P.; Chhonkar, P.K.; Suribabu, K. \& Singh, A.K. (2005). Long-term impact of irrigation with waste water effluents on heavy metal content in soils, crops and groundwater-a case study. Agr. Ecosyst. Environ. 109: 310-322.

Salardini, A. (1992). Soil Fertility. Tehran University Press, 440 pp.

Selivanovskaya, S.Y.; Latypova, V.Z.; Kiyamova S.N. \& Alimova, F.K. (2001). Use of microbial parameters to access treatment methods of municipal sewage sludge applied to grey forest soils of Tatars tan. Agriculture, Ecosystem and Environment, 86: 145-153.

Sharma, A. \& Ashwath, N. (2006). Land disposal of municipal effluents: Importance of choosing agroforestry systems. Desalination, 187: 361-374.

Sharma, R.K.; Agrawal, M. \& Marshall, F. (2007). Heavy metal contamination of soil and vegetables in suburban areas of Varanasi, India. Ecotox. Environ. Safe., 66: 258-266.

Singh, G. \& Bhati, M. (2005). Growth of Dalbergia sissoo in desert regions of western India using municipal effluent and plant chemistry. Bioresource Technology, 69: 1019-1028.

Stewart, H.T.L. \& Flinn, D.W. (1984). Establishment and early growth of trees irrigated with wastewater at four sites in Victoria, Australia. Forest Ecology and Management, 8: 243-256.

Stewart, H.T.L.; Hopmans, P.; Flinn, D.W. and Hillman, T.J. (1990). Nutrient accumulation in trees and soil following irrigation with municipal effluent in Australia. Environmental Pollution, 63: 155-177.

Tabatabaei, M. (1998). Sustainability in irrigation designs with wastewater. Journal of water and Environment, 31: 28-35.

Tajrishi, M. (1998). New and comprehensive outlook to the problem of municipal effluent of Tehran. The Journal of Water and Effluent, 28: 16-30.

Torabian, A. \& Hashemi, F. (1999). Irrigation of green space with treated wastewater of Tehran. The Journal of Water and Effluent, 29: 31-36. 
Toze, S. (2006). Reuse of effluent water-benefits and risks. Agr. Water Manage., 80: 147-159.

Wheeler, P.M.; Edmeades, D.C. \& Christie, R.A. (1992). Effect of aluminum on relative yield and plant chemical concentrations of cereals grown in solution culture at low ionic strength. J. Plant Nutr., 15: 403-418.

Yadav, R.K.; Goyal, B.; Sharma, R.K., Dubey, S.K. \& Minhas, P.S. (2002). Post-irrigation impact of domestic waste water effluent on composition of soils, crops and ground water-a case study. Environ. Int., 28: 481-486.

Zobeyri, M. (1994). Forest Inventory. Tehran University Press, 401 pp. 


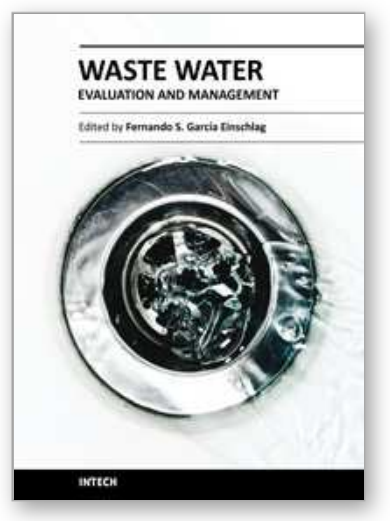

\author{
Waste Water - Evaluation and Management \\ Edited by Prof. Fernando Sebastĩ̃̃ $i n$ GarcÃa Einschlag
}

ISBN 978-953-307-233-3

Hard cover, 470 pages

Publisher InTech

Published online 01, April, 2011

Published in print edition April, 2011

Fresh water resources are under serious stress throughout the globe. Water supply and water quality degradation are global concerns. Many natural water bodies receive a varied range of waste water from point and/or non point sources. Hence, there is an increasing need for better tools to asses the effects of pollution sources and prevent the contamination of aquatic ecosystems. The book covers a wide spectrum of issues related to waste water monitoring, the evaluation of waste water effect on different natural environments and the management of water resources.

\title{
How to reference
}

In order to correctly reference this scholarly work, feel free to copy and paste the following:

Masoud Tabari, Azadeh Salehi and Jhangard Mohammadir (2011). Impact of Municipal Waste Water on Growth and Nutrition of Afforested Pinus eldarica Stands, Waste Water - Evaluation and Management, Prof. Fernando SebastiÃ $i n$ GarcÃa Einschlag (Ed.), ISBN: 978-953-307-233-3, InTech, Available from:

http://www.intechopen.com/books/waste-water-evaluation-and-management/impact-of-municipal-waste-wateron-growth-and-nutrition-of-afforested-pinus-eldarica-stands

\section{INTECH}

open science | open minds

\section{InTech Europe}

University Campus STeP Ri

Slavka Krautzeka 83/A

51000 Rijeka, Croatia

Phone: +385 (51) 770447

Fax: +385 (51) 686166

www.intechopen.com

\section{InTech China}

Unit 405, Office Block, Hotel Equatorial Shanghai

No.65, Yan An Road (West), Shanghai, 200040, China

中国上海市延安西路65号上海国际贵都大饭店办公楼405单元

Phone: +86-21-62489820

Fax: +86-21-62489821 
(C) 2011 The Author(s). Licensee IntechOpen. This chapter is distributed under the terms of the Creative Commons Attribution-NonCommercialShareAlike-3.0 License, which permits use, distribution and reproduction for non-commercial purposes, provided the original is properly cited and derivative works building on this content are distributed under the same license. 